\title{
EFEKTIVITAS HERBISIDA MONOAMONIUM GLIFOSAT UNTUK PENGENDALIAN GULMA DI BAWAH TEGAKAN SENGON DI PARUNG PANJANG, JAWA BARAT
}

\author{
Effectiveness of Monoamonium Glifosat Herbicide to Control Weeds Under Albizian Plantation \\ in Parung Panjang, West Java
}

Ari Wibowo dan/and M. Nazif

Pusat Litbang Hutan Tanaman

Kampus Litbang Kehutanan, Jl. Gunung Batu No. 5, Bogor 16610

Telp. (0251) 631238, Fax. (0251) 7520005

Naskah masuk : 07 Februari 2007 ; Naskah diterima : 25 Mei 2007

\begin{abstract}
Effectivenes of Monoamonium Glyphosate as active ingredient of herbicide to control weeds under Paraserianthes falcataria (L.) Nielsen plantation was trialed in Parung Panjang, West Java. The trial was conducted through application of Monoamonium Glyphosate Herbicide with dosages of 3, 4.5, 6 and 9 liter per ha and compared with Glyphosate herbicide 4.5 liter per ha, manual treatment and control (no treatment). The result showed that Monoamonium Glyphosate could be used to control weeds in order to maintain Paraserianthes falcataria (L.) Nielsen. plantation. Minimum dosage of 4.5 liter/ha was effective to control weeds such as Imperata cylindrica Beauv., Borreria latifolia DC. and Mikania micrantha Will, however the herbicide did not show effective result to control the growth of Chromolaena odorata DC weed. Furthermore, there was no symptom of poison on Paraserianthes falcataria (L.) Nielsen. plantation as the result of herbicide application with all dosages applied.
\end{abstract}

Key words: Herbicide, Paraserianthes falcataria (L.) Nielsen, weed control

\begin{abstract}
ABSTRAK
Efektivitas Monoamonium Glifosat sebagai bahan aktif herbisida telah diuji untuk mengendalikan gulma di bawah tegakan Paraserianthes falcataria (L.) Nielsen di Parung Panjang, Jawa Barat. Percobaan dilaksanakan melalui aplikasi herbisida Monoamonium Glifosat dengan dosis 3, 4,5, 6 dan 9 liter per ha serta membandingkannya dengan herbisida dengan bahan aktif Glifosat 4,5 liter per ha, perlakuan manual and kontrol (tanpa perlakuan). Hasil percobaan menunjukkan bahwa Herbisida Monoamonium Glifosat dapat digunakan sebagai sarana pemeliharaan tanaman kehutanan dari gangguan gulma di bawah tegakan Paraserianthes falcataria. Selanjutnya Herbisida Monoamonium Glifosat dengan minimum dosis 4,5 liter/ha efektif untuk mengendalikan gulma Imperata cylindrica Beauv., Borreria latifolia DC. dan Mikania micrantha Will. Meskipun demikian herbisida ini tidak efektif untuk mengendalikan pertumbuhan gulma Chromolaena odorata DC. Pada tanaman Paraserianthes falcataria (L.) Nielsen tidak tampak gejala keracunan akibat penggunaan herbisida Monoamonium Glifosat pada semua tingkat dosis yang dicobakan.
\end{abstract}

Kata kunci: Herbisida, pengendalian gulma, Paraserianthes falcataria (L.) Nielsen 


\section{PENDAHULUAN}

Paraserianthes falcataria (L.) Nielsen yang dahulu disebut Albizia falcataria Beck. atau sengon atau jeunjing merupakan jenis tanaman yang berasal dari Indonesia Timur dan banyak ditanam di Jawa Barat. Jenis ini merupakan jenis serba guna yang cepat tumbuh dan bahkan disebut sebagai pohon ajaib (National Academy of Sciences, 1979) karena pertumuhannya begitu cepat. Dilaporkan bahwa pada kondisi tanah yang baik dan curah hujan cukup, jenis ini dapat mencapai dimensi tinggi 7 meter pada umur 1 tahun, 13-18 meter pada umur tiga tahun, 21 meter pada umur 4 tahun, serta 30 meter pada umur 9-10 tahun.

Jenis ini mempunyai banyak manfaat, kayunya mempunyai serat yang baik sebagai bahan baku pulp dan kertas, sedangkan oleh masyarakat, kayu jeunjing banyak digunakan untuk papan, kotak kemasan dan furniture ringan. Salah satu masalah yang timbul dengan meningkatnya. penanaman jenis sengon adalah gangguan gulma. Tajuk yang tipis dari jenis sengon memungkinkan masuknya cahaya dan berkembangnya berbagai jenis tumbuhan bawah sebagai gulma yang merupakan saingan bagi tanaman pokok. Kehadiran gulma di sekitar tanaman kehutanan tidak dapat dielakkan sebagai tumbuhan pengganggu karena gulma juga memerlukan persyaratan tumbuh seperti halnya tanaman lain yaitu kebutuhan akan cahaya, nutrisi, air dan ruang tempat tumbuh. Hal ini dapat berakibat merugikan yaitu terjadinya persaingan antara gulma dan tanaman kehutanan, yang apabila tidak dikendalikan dapat menghambat pertumbuhan tanaman pokok.

Salah satu metode yang dapat digunakan untuk mengendalikan gulma secara cepat adalah secara kimiawi dengan menggunakan herbisida. Herbisida dengan bahan aktif Monoamonium Glifosat merupakan herbisida yang mulai banyak dijumpai di pasar. Herbisida ini direkomendasikan untuk pengendalian gulma di bawah tegakan karet dan tumbuhan berkayu lainnya.

Dalam rangka pemeliharaan tanaman kehutanan terutama dari gangguan gulma diperlukan pengetahuan mengenai pengendalian gulma. Untuk tanaman kehutanan dengan kondisi lingkungan yang berbeda dari tanaman perkebunan serta karakteristik jenis tertentu seperti sengon, diperlukan uji coba herbisida ini untuk mengetahui efektivitasnya dalam mengendalikan gulma. Dengan demikian, penelitian ini bertujuan untuk mengetahui efektivitas herbisida dengan bahan aktif Monoamonium Glifosat dalam pengendalian gulma di bawah tegakan $P$. falcataria, guna mendapatkan dosis yang tepat dan ekonomis bagi penggunaan herbisida tersebut. Selain itu, uji coba juga dimaksudkan untuk mengetahui tingkat keracunan tanaman pokok akibat penggunaan herbisida.

\section{BAHAN DAN METODE}

\section{A. Risalah Daerah Penelitian}

Penelitian dilakukan pada bulan Maret - Juni tahun 2004 di kawasan hutan Perum Perhutani Unit III Jawa Barat. Daerah ini termasuk dalam wilayah Kesatuan Pemangkuan Hutan (KPH) Bogor, Bagian Kesatuan Pemangkuan Hutan (BKPH) Parung Panjang dan Resort Polisi Hutan (RPH) Jagabaya. Secara admistrasi pemerintahan daerah ini termasuk Desa Tenjo, Kabupaten Bogor berjarak lebih kurang 100 km sebelah barat Kota Bogor.

Dengan menggunakan data curah hujan di Parung Panjang, daerah penelitian termasuk tipe iklim A (Schmidt \& Ferguson, 1951), dengan curah hujan rata-rata 2712 mm/tahun. 
Tanah daerah penelitian ini tergolong tanah aluvial kelabu dan aluvial kekelabuan dengan bahan induk endapan liat dan pasir (Lembaga Penelitian Tanah, 1966). Keadaan topografi di lokasi penelitian umumnya bergelombang ringan.

Lokasi penelitian merupakan hutan tanaman $P$. falcataria berumur dua tahun dengan jarak tanam 4 x 3 meter persegi. Gulma yang mendominasi daerah penelitian adalah Imperata cylindrica (alang-alang) dan jenis lainnya yaitu Borreria latifolia, Chromolaena odorata dan Mikania micrantha, yang dijumpai secara berkelompok dan tersebar merata.

\section{B. Bahan dan Alat}

Bahan dalam penelitian ini adalah sampel herbisida dengan bahan aktif Monoamonium Glifosat 130 g/liter yang dikeluarkan oleh Komisi Pestisida di Jakarta, alat tulis, kantong plastik, cat, tali rafia, seng, papan nama dan film. Alat-alat yang diperlukan adalah foto tustel, arit, cangkul, gelas ukur, kaliper, galah ukur, meteran, timbangan dan hand sprayer dengan nozzel polizet biru yang mempunyai lebar semprotan 1,5 meter dan keluaran larutan semprotan sekitar 1.263 cc/menit.

\section{Metode Pengumpulan Data}

1. Inventarisasi jenis gulma

Jenis gulma di bawah tegakan $P$. falcataria diinventarisir dengan metode penarikan contoh melalui petak-petak coba berukuran standar. Petak-petak contoh berukuran 1 meter x 1 meter dibuat dalam jalur di bawah tegakan (Odum, 1971, Soerianegara dan Indrawan, 1978). Jumlah petak contoh sebanyak 25 petak yang diletakkan dalam lima jalur sepanjang 25 meter. Jarak antara jalur 20 meter dan jarak antara titik pusat petak 5 meter.

Setiap jenis tumbuhan bawah yang ada disetiap petak coba dicatat jumlahnya dan diukur luas proyeksi penutupan tajuk. Herbarium dikumpulkan untuk diidentifikasi pada Pusat Litbang Hutan dan Konservasi Alam dan data yang diperoleh dianalisis untuk menentukan jenis yang dominan.

Jenis-jenis yang dominan merupakan jenis yang mempunyai Nilai Penting tertinggi pada tipe vegetasi yang bersangkutan.

\section{Perlakuan}

Pada 32 petak coba berukuran masing-masing $10 \mathrm{~m} \mathrm{x} 20 \mathrm{~m}\left(200 \mathrm{~m}^{2}\right)$ dengan delapan perlakuan seperti tertera pada Tabel 1, masing-masing perlakuan diulang sebanyak empat kali. 
Tabel (Table) 1. Perlakuan herbisida Monoamonium Glifosat di bawah tegakan Paraserianthes falcataria di Parung Panjang, Jawa Barat (Treatments of monoamium glyphosate herbicide under Paraserianthes falcataria plantation in Parung Panjang, West Java)

\begin{tabular}{|c|l|c|l|}
\hline $\begin{array}{c}\text { Perlakuan } \\
\text { (Treatment) }\end{array}$ & \multicolumn{1}{|c|}{$\begin{array}{c}\text { Herbisida } \\
\text { (Herbicide) }\end{array}$} & $\begin{array}{c}\text { Dosis/ha dengan 500 } \\
\text { It lar/ha (Dosage/ha } \\
\text { in 500 liter } \\
\text { solution/ha) }\end{array}$ & $\begin{array}{c}\text { Cara aplikasi } \\
\text { (Application method) }\end{array}$ \\
\hline 1 & Monoamonium Glifosat & $3,0 \mathrm{lt}$ & $\begin{array}{l}\text { Disemprotkan langsung ke seluruh } \\
\text { petak coba (applied to all of test } \\
\text { plots) }\end{array}$ \\
\hline 2 & Monoamonium Glifosat & $4,5 \mathrm{lt}$ & Idem \\
\hline 3 & Monoamonium Glifosat & $6,0 \mathrm{lt}$ & Idem \\
\hline 4 & Monoamonium Glifosat & $7,5 \mathrm{lt}$ & Idem \\
\hline 5 & Monoamonium Glifosat & $9,0 \mathrm{lt}$ & Idem \\
\hline 6 & Glifosat 480 AS & $4,5 \mathrm{lt}$ & $\begin{array}{l}\text { Dibabat sampai permukaan tanah } \\
\text { oleh tenaga manusia (total deared } \\
\text { by men) }\end{array}$ \\
\hline 7 & Manual (manual) & - & Dibiarkan (abandoned) \\
\hline 8 & Kontrol (control) & - &
\end{tabular}

Perlakuan 6, 7 dan 8 sebagai pembanding merupakan perlakuan alternatif dan tanpa perlakukan yang selama ini banyak dilakukan untuk pengendalian gulma. Perlakukan ini digunakan sebagai pembanding untuk mengetahui efektifitas herbisida yang dicoba dalam mengendalikan jenis gulma tertentu.

a. Pengambilan biomas gulma sesudah perlakuan dilakukan dengan cara sebagai berikut:

1) Jumlah contoh gulma yang diamati pada tiap pengamatan adalah lima petak ukuran $0,5 \times 0,5$ meter persegi yang terletak di setiap ujung petak dan di tengah petak.

2) Pengambilan contoh dilakukan dengan cara memotong seluruh biomas gulma sampai permukaan tanah. Kemudian setiap bagian biomas yang masih hidup/hijau dan yang sudah mati dipisahkan. Bagian yang masih hidup dikeringkan sampai kering konstan dan ditimbang beratnya.

3) Pengamatan biomas gulma sesudah perlakuan dilakukan pada satu, dua, dan tiga bulan setelah aplikasi herbisida.

b. Tingkat keracunan herbisida terhadap tanaman pokok diamati setelah 4, 8, dan 12 minggu aplikasi herbisida yang ditentukan dengan skoring visual ( Tabel 2). 
Tabel (Table) 2. Skoring visual tingkat keracunan tanaman pokok Paraserianthes falcataria akibat perlakuan herbisida dengan bahan aktif Monoamonium Glifosat di Parung Panjang, Jawa Barat (Visual scoring of poisonous level of Paraserianthes falcataria plantation due to treatments of monoamium glyphosate herbicide in Parung Panjang, West Java (Sumber/Source : Komisi Pestisida, 1994)

\begin{tabular}{|c|l|}
\hline $\begin{array}{c}\text { Skor } \\
\text { (Score) }\end{array}$ & $\begin{array}{l}\text { Gejala Keracunan } \\
\text { (Poisonous symptom) }\end{array}$ \\
\hline 0 & $\begin{array}{l}\text { Tidak ada keracunan, 0-5 \% bentuk atau warna daun muda mengalami sedikit perubahan. (No } \\
\text { poisoning, 0-5 \% of malformation or discoloration of young leaves) }\end{array}$ \\
\hline 1 & $\begin{array}{l}\text { Keracunan ringan, 6-10\% bentuk atau warna daun muda tidak normal. } \\
\text { (Light poisoning, 6-10\% of abnormal form or color of young leaves) }\end{array}$ \\
\hline 2 & $\begin{array}{l}\text { Keracunan sedang, 11-20 \% bentuk atau warna daun muda tidak normal. } \\
\text { (Medium poisoning, 11-20\% of abnormal form or color of young leaves) }\end{array}$ \\
\hline 3 & $\begin{array}{l}\text { Keracunan berat, 21-50 \% bentuk warna daun muda tidak normal. } \\
\text { (Hard poisoning, 21-50\% of abnormal form or color of young leaves) }\end{array}$ \\
\hline 4 & $\begin{array}{l}\text { Keracunan sangat berat, >50 \% bentuk atau warna daun muda tidak normal hingga mengering } \\
\text { dan rontok sampai tanaman mati. (Very hard poisoning of abnormal form or color of young } \\
\text { leaves, dry and fall) }\end{array}$ \\
\hline
\end{tabular}

c. Selain skoring visual dengan indikator perubahan warna daun seperti pada Tabel 2, pertumbuhan diameter tanaman pokok 0, 1, 2, dan 3 bulan setelah aplikasi herbisida juga diukur. Pada tanaman kehutanan yang relatif mempunyai daur hidup yang lama, pertumbuhan diameter selama 3 bulan sangat kecil dan mungkin tidak signifikan untuk membuktikan bahwa perbedaan diameter pohon pada petak pengamatan adalah akibat dari pengaruh perlakuan.

\section{Pengolahan Data}

Untuk mengetahui jenis gulma yang dominan dilakukan analisis dengan menghitung Nilai Penting (Important Value) dari masing-masing jenis. Indeks Nilai Penting (NP) (\%) = Kerapatan Relatif (KR) + Frekuensi Relatif (FR) + Dominasi Relatif (DR) (Odum, 1971, Soerianegara dan Indrawan, 1978).

Untuk mengetahui perbedaan perlakuan digunakan rancangan percobaan acak kelompok (randomized complete block design), yang terdiri dari delapan perlakuan dan empat ulangan. Pengolahan data dikerjakan sesuai rancangan percobaan yang digunakan. Tingkat perbedaan biomas gulma dinyatakan pada taraf $5 \%$ dan $1 \%$ (Steel and Torrie, 1980).

\section{HASIL DAN PEMBAHASAN}

\section{A. Jenis Gulma Dominan}

Dari hasil inventarisasi dan analisis jenis tumbuhan bawah di bawah tanaman $P$. falcataria umur dua tahun diperoleh 16 jenis tumbuhan bawah. Jenis dominan dengan nilai penting tertinggi dalam tipe vegetasi yang bersangkutan terlihat pada Tabel 3. 
Tabel (Table) 3. Indeks nilai penting jenis tumbuhan di bawah tegakan Paraserianthes falcataria umur dua tahun di Parung Panjang, Jawa Barat. (Important value indices of undergrowth species under two years old Paraserianthes falcataria plantation in Parung Panjang, West Java)

\begin{tabular}{|c|c|c|c|c|c|c|}
\hline No & $\begin{array}{l}\text { Nama Jenis } \\
\text { (Species) }\end{array}$ & $\begin{array}{c}\text { Famili } \\
\text { (Family) }\end{array}$ & $\begin{array}{c}\text { KR } \\
\text { (RD) } \\
(\%) \\
\end{array}$ & $\begin{array}{c}\text { FR } \\
\text { (RF) } \\
(\%) \\
\end{array}$ & $\begin{array}{c}\text { DR (RD) } \\
(\%)\end{array}$ & $\begin{array}{c}\text { NP (IV) } \\
(\%)\end{array}$ \\
\hline 1 & Imperata cylindrica Beauv. & Gram. & 51,75 & 12,16 & 11,29 & 75,20 \\
\hline 2 & Borreria latifolia DC. & Rubi. & 26,87 & 13,51 & 22,13 & 62,51 \\
\hline 3 & Chromolaena odorata DC. & Comp. & 4,79 & 8,11 & 19,87 & 32,77 \\
\hline 4 & Mikania micranta Will. & Comp. & 3,30 & 10,81 & 14,45 & 28,56 \\
\hline 5 & Sacharum spontaneum L. & Gram. & 3,00 & 8,11 & 6,78 & 17,89 \\
\hline 6 & Lantana camara L. & Verben. & 1,59 & 6,76 & 6,32 & 14,67 \\
\hline 7 & Melastoma malabathricum L. & Melast. & 2,00 & 9,46 & 2,17 & 13,63 \\
\hline 8 & Mimosa pudica Mim. & Mim. & 0,60 & 4,05 & 6,32 & 10,79 \\
\hline 9 & Clibadium surinamense L. & Comp. & 1,30 & 5,41 & 3,16 & 9,87 \\
\hline 10 & Solanum torvum Sw. & Solan. & 0,80 & 5,41 & 1,81 & 8,02 \\
\hline 11 & Paspalum conjugatum L. & Gram. & 1,30 & 4,05 & 1,36 & 6,71 \\
\hline 12 & Ageratum conyzoides L. & Comp. & 0,90 & 4,05 & 1,36 & 6,31 \\
\hline 13 & Blumea lacera DC. & Comp. & 0,70 & 2,70 & 1,36 & 4,76 \\
\hline 14 & Erechtites valerianifolia Raf. & Comp. & 0,30 & 2,70 & 0,72 & 3,72 \\
\hline 15 & Trema orientalis BL. & Ulm. & 0,50 & 1,35 & 0,45 & 2,30 \\
\hline 16 & Cyperus compressus L. & Gram. & 0,30 & 1,35 & 0,45 & 2,10 \\
\hline \multicolumn{3}{|c|}{ Jumlah Nilai Penting (Important Value Total) } & 100,0 & 100,0 & 100,0 & 299,8 \\
\hline
\end{tabular}

Komposisi tumbuhan bawah di bawah tegakan $P$. falcataria didominasi oleh gulma alangalang (Imperata cylindrica) dengan indeks nilai penting 75,2 \%. Dominasi jenis alang-alang, selain disebabkan oleh umur tegakan sengon yang relatif masih muda (umur 2 tahun dengan rata-rata tinggi 5,3 meter dan diameter 8,2 cm) sehingga tajuk belum tumbuh optimal, juga disebabkan oleh karakteristik tajuk tegakan sengon yang tipis sehingga memungkinkan masuknya cahaya matahari. Alang-alang sebagai jenis yang membutuhkan cahaya (intoleran) akan mendominasi areal yang terbuka. Jenis lain yang juga dominan adalah Borreria latifolia ( $\mathrm{NP}=62,5 \%)$, Chromolaena odorata $(\mathrm{NP}=32,8 \%)$ dan Mikania micrantha $(\mathrm{NP}=28,6 \%)$. Gulma mikania meskipun telah digunakan di perkebunan untuk pengendalian alang-alang, pada lokasi penelitian merupakan gulma yang tumbuh liar dan masuk ke areal tanaman karena kondisi lahan yang relatif terbuka.

\section{B. Pengendalian Gulma}

Pengendalian gulma di bawah tegakan $P$. falcataria dilakukan dengan memakai herbisida dengan bahan aktif Monoamonium Glifosat. Di pasaran herbisida ini dijual dengan merk dagang Spark 130/5 AS sebagai produk dari PT. Monagro Kimia (Monsanto). Herbisida ini bersifat sistemik yang mengandung bahan aktif 130 gram/liter Mono Amonium Glifosat dan 5 gram/liter Glifosinat. 
Herbisida ini mempunyai sifat cepat terurai dalam tanah, sehingga penggunaannya tidak meninggalkan efek residu meskipun terhisap oleh akar tanaman dan tidak menimbulkan keracunan terhadap tanaman pokok. Pengujian herbisida Monoamonium Glifosat di bawah tegakan P. falcataria dititikberatkan pada berat kering bagian atas (daun dan batang) gulma.

1. Berat kering gulma Imperata cylindrica

Hasil pengamatan rata-rata berat kering gulma I. cylindrica setelah aplikasi herbisida Monoamonium Glifosat selama tiga bulan pengamatan tertera dalam Tabel 4.

Tabel (Table) 4. Biomas gulma Imperata cylindrica selama tiga bulan setelah aplikasi herbisida dengan bahan aktif Monoamonium Glifosat di bawah tegakan Paraserianthes falcataria di Parung Panjang, Jawa Barat (Biomass of Imperata cylindrica up to three months after application of monoamium glyphosate herbicide in Parung Panjang, West Java)

\begin{tabular}{|c|l|c|c|c|c|}
\hline \multirow{2}{*}{ No. } & \multirow{2}{*}{$\begin{array}{c}\text { Perlakuan } \\
\text { (Treatment) }\end{array}$} & \multirow{2}{*}{$\begin{array}{c}\text { Dosis } \\
\text { (Dosage) } \\
\end{array}$} & & \multicolumn{3}{|c|}{$\begin{array}{c}\text { Biomas Gulma (Weed Biomass) } \\
\text { (Ton/Ha) }\end{array}$} \\
\cline { 4 - 6 } & & $\begin{array}{c}\text { 1 Bulan } \\
\text { (Month) }\end{array}$ & $\begin{array}{c}\text { 2 Bulan } \\
\text { (Month) }\end{array}$ & $\begin{array}{c}\text { 3 Bulan } \\
\text { (Month) }\end{array}$ \\
\hline 1 & Monoamonium Glifosat & 3,0 & $10,562 \mathrm{a}$ & $11,562 \mathrm{a}$ & $13,437 \mathrm{a}$ \\
\hline 2 & Monoamonium Glifosat & 4,5 & $8,562 \mathrm{~b}$ & $3,875 \mathrm{~b}$ & $0,625 \mathrm{~b}$ \\
\hline 3 & Monoamonium Glifosat & 6,0 & $8,125 \mathrm{~b}$ & $3,125 \mathrm{~b}$ & $0,375 \mathrm{~b}$ \\
\hline 4 & Monoamonium Glifosat & 7,5 & $7,375 \mathrm{bc}$ & $2,875 \mathrm{~b}$ & $0,125 \mathrm{~b}$ \\
\hline 5 & Monoamonium Glifosat & 9,0 & $6,500 \mathrm{c}$ & $2,062 \mathrm{~b}$ & $0,125 \mathrm{~b}$ \\
\hline 6 & Glifosat 480 AS & 4,5 & $7,687 \mathrm{~b}$ & $2,750 \mathrm{~b}$ & $0,312 \mathrm{~b}$ \\
\hline 7 & Manual & - & $2,875 \mathrm{~d}$ & $7,750 \mathrm{c}$ & $12,937 \mathrm{a}$ \\
\hline 8 & Kontrol & - & $12,562 \mathrm{e}$ & $13,562 \mathrm{~d}$ & $14,187 \mathrm{a}$ \\
\hline
\end{tabular}

Keterangan: Angka yang diikuti oleh huruf yang sama tidak berbeda nyata pada tingkat $99 \%$ (remarks) (number followed by the same letter are insignificantly different at 99\% level)

Pada Tabel 4 terlihat bahwa aplikasi perlakuan herbisida hingga tiga bulan berbeda nyata dengan kontrol dan manual. Sedangkan antara perlakuan herbisida tidak berbeda nyata kecuali pada perlakuan herbisida dosis 3,0 liter/ha. Hasil analisis ini menunjukkan bahwa herbisida Monoamonium Glifosat dengan dosis minimal 4,5 liter/ha efektif untuk mengendalikan gulma I. cylindrica di bawah tegakan P. falcataria.

Rendahnya biomasa gulma alang-alang setelah perlakuan menunjukkan bahwa herbisida dengan bahan aktif monoamonium glifosat merupakan herbisida sistemik yang mampu menekan dan membunuh gulma alang-alang dengan mematikan rizoma alang-alang yang berada di bawah permukaan tanah.

\section{Berat kering gulma Borreria latifolia}

Pengamatan berat kering gulma B. latifolia setelah aplikasi herbisida Monoamonium Glifosat selama tiga bulan (Tabel 5). 
Tabel (Table ) 5. Biomas gulma Borreria latifolia selama tiga bulan setelah aplikasi herbisida dengan bahan aktif Monoamonium Glifosat di bawah tegakan Paraserianthes falcataria di Parung Panjang, Jawa Barat. (Biomass of Borreria latifolia up to three months after application of Monoamium glyphosate herbicide in Parung Panjang, West Java)

\begin{tabular}{|c|l|c|c|c|c|}
\hline \multirow{2}{*}{ No. } & \multirow{2}{*}{$\begin{array}{c}\text { Perlakuan } \\
\text { (Treatment) }\end{array}$} & \multirow{2}{*}{$\begin{array}{c}\text { Dosis (Dosage) } \\
(\mathbf{l} / \mathbf{h a})\end{array}$} & \multicolumn{3}{|c|}{$\begin{array}{c}\text { Biomas Gulma (Weed Biomass) } \\
\text { (Ton/Ha) }\end{array}$} \\
\cline { 4 - 6 } & & & $\begin{array}{c}\text { 1 Bulan } \\
\text { (Month) }\end{array}$ & $\begin{array}{c}\text { 2 Bulan } \\
\text { (Month) }\end{array}$ & $\begin{array}{c}\text { 3 Bulan } \\
\text { (Month) }\end{array}$ \\
\hline 1 & Monoamonium Glifosat & 3,0 & $10,000 \mathrm{a}$ & $12,375 \mathrm{a}$ & $12,562 \mathrm{a}$ \\
\hline 2 & Monoamonium Glifosat & 4,5 & $8,250 \mathrm{~b}$ & $3,875 \mathrm{~b}$ & $0,875 \mathrm{~b}$ \\
\hline 3 & Monoamonium Glifosat & 6,0 & $6,562 \mathrm{c}$ & $3,062 \mathrm{~b}$ & $0,562 \mathrm{~b}$ \\
\hline 4 & Monoamonium Glifosat & 7,5 & $5,875 \mathrm{c}$ & $2,562 \mathrm{~b}$ & $0,375 \mathrm{~b}$ \\
\hline 5 & Monoamonium Glifosat & 9,0 & $5,750 \mathrm{c}$ & $2,375 \mathrm{c}$ & $0.375 \mathrm{~b}$ \\
\hline 6 & Glifosat 480 AS & 4,5 & $5,875 \mathrm{c}$ & $3,187 \mathrm{bc}$ & $0,437 \mathrm{~b}$ \\
\hline 7 & Manual & - & $2,625 \mathrm{~d}$ & $6,250 \mathrm{~d}$ & $9,812 \mathrm{c}$ \\
\hline 8 & Kontrol (control) & - & $12,687 \mathrm{e}$ & $12,625 \mathrm{a}$ & $12,750 \mathrm{a}$ \\
\hline
\end{tabular}

Keterangan: Angka yang diikuti oleh huruf yang sama tidak berbeda nyata pada tingkat $99 \%$ (remarks): (numbers followed by the same letters are insignificantly different at 99\% level)

Pada Tabel 5 terlihat bahwa aplikasi perlakuan herbisida hingga tiga bulan berbeda nyata dengan kontrol dan manual kecuali pada perlakuan herbisida dengan dosis 3,0 liter /ha. Dengan demikian dapat dikatakan bahwa herbisida Monoamonium Glifosat dengan dosis minimal 4,5 liter/ha efektif untuk mengendalikan gulma B. latifolia di bawah tegakan $P$. falcataria.

3. Berat kering gulma Chromolaena odorata

Pengamatan rata-rata berat kering gulma $C$. odorata setelah aplikasi herbisida Monoamonium Glifosat selama tiga bulan tertera dalam Tabel 6.

Pada Tabel 6 terlihat bahwa aplikasi perlakuan herbisida hingga tiga bulan tidak berbeda nyata dengan kontrol kecuali dengan perlakuan manual. Sedangkan antara perlakuan herbisida tidak berbeda nyata. Dengan demikian dapat dikatakan bahwa penggunaan herbisida Monoamonium Glifosat tidak efektif mengendalikan gulma $C$. odorata di bawah tegakan $P$. falcataria. 
Tabel (Table) 6. Biomas gulma Chromolaena odorata selama tiga bulan setelah aplikasi herbisida dengan bahan aktif Monoamonium Glifosat di bawah tegakan Paraserianthes falcataria di Parung Panjang, Jawa Barat (Biomass of Chromolaena odorata up to three months after application of monoamium glyphosate herbicide in Parung Panjang, West Java)

\begin{tabular}{|c|c|c|c|c|c|}
\hline \multirow[t]{2}{*}{ No. } & \multirow{2}{*}{$\begin{array}{c}\text { Perlakuan } \\
\text { (Treatment) }\end{array}$} & \multirow{2}{*}{$\begin{array}{c}\text { Dosis } \\
\text { (Dosage) } \\
\text { (l/ha) }\end{array}$} & \multicolumn{3}{|c|}{$\begin{array}{l}\text { Biomas Gulma (Weed Biomass) } \\
\text { (Ton/Ha) }\end{array}$} \\
\hline & & & $\begin{array}{l}1 \text { Bulan } \\
\text { (Month) }\end{array}$ & $\begin{array}{l}2 \text { Bulan } \\
\text { (Month) }\end{array}$ & $\begin{array}{l}3 \text { Bulan } \\
\text { (Month) }\end{array}$ \\
\hline 1 & Monoamonium Glifosat & 3,0 & $21,562 \mathrm{a}$ & $22,062 \mathrm{a}$ & $22,187 \mathrm{a}$ \\
\hline 2 & Monoamonium Glifosat & 4,5 & $21,875 \mathrm{a}$ & $22,375 \mathrm{a}$ & $22,500 \mathrm{a}$ \\
\hline 3 & Monoamonium Glifosat & 6,0 & 21,500 a & $22,250 \mathrm{a}$ & $22,375 \mathrm{a}$ \\
\hline 4 & Monoamonium Glifosat & 7,5 & $17,062 \mathrm{~b}$ & $21,500 \mathrm{a}$ & 21,812 a \\
\hline 5 & Monoamonium Glifosat & 9,0 & $16,125 \mathrm{~b}$ & $21,250 \mathrm{a}$ & $22,000 \mathrm{a}$ \\
\hline 6 & Glifosat 480 AS & 4,5 & 20,375 a & $22,000 \mathrm{a}$ & $22,687 \mathrm{a}$ \\
\hline 7 & Manual & - & $7,625 \mathrm{c}$ & $12,500 \mathrm{~b}$ & $15,437 \mathrm{~b}$ \\
\hline 8 & Kontrol (control) & - & $22,000 \mathrm{a}$ & $22,750 \mathrm{a}$ & $23,187 \mathrm{a}$ \\
\hline
\end{tabular}

Keterangan : Angka yang diikuti oleh huruf yang sama tidak berbeda nyata pada tingkat $99 \%$

(remarks) : (numbers followed by the same lettes are insignificantly diffeent at 99\% level)r

\section{Berat kering gulma Mikania micrantha.}

Pengamatan berat kering gulma $M$. micrantha setelah aplikasi herbisida Monoamonium Glifosat selama tiga bulan tertera dalam Tabel 7.

Tabel (Table) 7. Biomas gulma Mikania micrantha selama tiga bulan setelah aplikasi herbisida dengan bahan aktif Monoamonium Glifosat di bawah tegakan Paraserianthes falcataria di Parung Panjang, Jawa Barat (Biomass of Mikania micrantha up to three months after application of monoamium glyphosate herbicide in Parung Panjang, West Java)

\begin{tabular}{|c|l|c|c|c|c|}
\hline \multirow{2}{*}{ No. } & \multicolumn{1}{|c|}{$\begin{array}{c}\text { Perlakuan } \\
\text { (Treatment) }\end{array}$} & \multirow{2}{*}{$\begin{array}{c}\text { Dosis (Dosage) } \\
\text { (l/ha) }\end{array}$} & \multicolumn{3}{|c|}{$\begin{array}{c}\text { Biomas Gulma (Weed Biomass) } \\
\text { (Ton/Ha) }\end{array}$} \\
\cline { 4 - 6 } & \multicolumn{1}{|c|}{$\begin{array}{c}\text { 1 Bulan } \\
\text { (Month) }\end{array}$} & $\begin{array}{c}\text { 2 Bulan } \\
\text { (Month) }\end{array}$ & $\begin{array}{c}\text { 3 Bulan } \\
\text { (Month) }\end{array}$ \\
\hline 1 & Monoamonium Glifosat & 3,0 & $10,375 \mathrm{a}$ & $11,375 \mathrm{a}$ & $12,062 \mathrm{a}$ \\
\hline 2 & Monoamonium Glifosat & 4,5 & $8,562 \mathrm{~b}$ & $4,437 \mathrm{~b}$ & $1,125 \mathrm{~b}$ \\
\hline 3 & Monoamonium Glifosat & 6,0 & $7,187 \mathrm{bc}$ & $3,937 \mathrm{~b}$ & $0,500 \mathrm{~b}$ \\
\hline 4 & Monoamonium Glifosat & 7,5 & $6,125 \mathrm{c}$ & $4,187 \mathrm{~b}$ & $0,250 \mathrm{~b}$ \\
\hline 5 & Monoamonium Glifosat & 9,0 & $5,687 \mathrm{c}$ & $3,437 \mathrm{~b}$ & $0,187 \mathrm{~b}$ \\
\hline 6 & Glifosat 480 AS & 4,5 & $6,250 \mathrm{c}$ & $3,652 \mathrm{~b}$ & $0,687 \mathrm{~b}$ \\
\hline 7 & Manual & - & $2,937 \mathrm{~d}$ & $6,937 \mathrm{c}$ & $11,937 \mathrm{a}$ \\
\hline 8 & Kontrol (control) & - & $11,687 \mathrm{a}$ & $12,000 \mathrm{a}$ & $12,125 \mathrm{a}$ \\
\hline
\end{tabular}

Keterangan : $\quad$ Angka yang diikuti oleh huruf yang sama tidak berbeda nyata pada tingkat $99 \%$ (remarks) (number followed by the same letter are insignificantly different at $99 \%$ level)

Pada Tabel 7 terlihat bahwa aplikasi perlakuan berbagai dosis herbisida hingga tiga bulan berbeda nyata bila dibandingkan dengan kontrol dan perlakuan manual kecuali pada perlakuan herbisida dengan dosis 3,0 liter/ha yang tidak berbeda nyata. Dengan demikian dapat dikatakan bahwa herbisida Monoamonium Glifosat minimal dosis 4,5 liter/ha efektif untuk mengendalikan gulma M. micrantha di bawah tegakan P. falcataria. 


\section{Tingkat keracunan herbisida terhadap tanaman pokok}

Dari hasil pengamatan hingga tiga bulan setelah aplikasi, ternyata tingkat keracunan tanaman pokok akibat perlakuan herbisida Monoamonium Glifosat pada beberapa macam dosis yang digunakan mempunyai nilai (skoring) rata-rata 0 (kriteria pada Tabel 2). Tidak terjadi perubahan warna daun pada tanaman pokok akibat perlakuan herbisida. Hal ini menunjukkan bahwa aplikasi herbisida dengan menyemprot hanya pada sekeliling tanaman (tidak mengenai tanaman pokok) tidak mengakibatkan efek keracunan terhadap tanaman pokok. Tanaman pokok tidak mengalami gangguan dalam bentuk perubahan warna daun atau pertumbuhannya.

\section{Pertumbuhan tanaman Paraserianthes falcataria}

Berdasarkan data pengamatan rata-rata diameter tanaman menunjukan bahwa herbisida Monoamonium Glifosat dengan beberapa macam dosis yang dicobakan, tidak menghambat dan tidak memberikan akibat yang negatif terhadap pertumbuhan diameter tanaman (Tabel 8).

Tabel (Table) 8. Diameter rata-rata tanaman Paraserianthes falcataria pada berbagai perlakuan di Parung Panjang, Jawa Barat (Average diameter of Paraserianthes falcataria at several treatments in Parung Panjang, West Java)

\begin{tabular}{|c|c|c|c|c|c|c|}
\hline \multirow[b]{2}{*}{ No. } & \multirow[b]{2}{*}{$\begin{array}{c}\text { Perlakuan } \\
\text { (Treatment) }\end{array}$} & \multirow[b]{2}{*}{$\begin{array}{c}\text { Dosis } \\
\text { (Dosage) } \\
\text { (l/ha) }\end{array}$} & \multicolumn{4}{|c|}{ Diameter rata-rata (Average diameter) $(\mathrm{Cm})$} \\
\hline & & & $\begin{array}{c}\text { 0 Bulan } \\
\text { (0 Month) }\end{array}$ & $\begin{array}{c}1 \text { Bulan } \\
\text { (1 Month) }\end{array}$ & $\begin{array}{c}2 \text { Bulan } \\
\text { (2 Month) }\end{array}$ & $\begin{array}{c}\text { 3 Bulan } \\
\text { (3 Month) }\end{array}$ \\
\hline 1 & Monoamonium Glifosat & 3,0 & 7,7 & 8,1 & 8,4 & 8,7 \\
\hline 2 & Monoamonium Glifosat & 4,5 & 7,6 & 8,0 & 8,5 & 8,9 \\
\hline 3 & Monoamonium Glifosat & 6,0 & 7,1 & 7,9 & 8,3 & 8,8 \\
\hline 4 & Monoamonium Glifosat & 7,5 & 7,7 & 8,0 & 8,3 & 8,8 \\
\hline 5 & Monoamonium Glifosat & 9,0 & 7,8 & 8,4 & 8,8 & 9,3 \\
\hline 6 & Roundup 480 AS & 4,5 & 6,7 & 8,7 & 9,0 & 9,5 \\
\hline 7 & Manual & - & 7,8 & 8,1 & 8,4 & 8,7 \\
\hline 8 & Kontrol & - & 7,5 & 7,7 & 8,1 & 8,4 \\
\hline
\end{tabular}

Pertumbuhan tanaman $P$. falcataria tersebut dapat digambarkan dalam grafik pertumbuhan seperti tersaji pada Gambar 1. Paraserianthes falcataria merupakan jenis yang cepat tumbuh, dari Gambar 1 terlihat bahwa pertumbuhan diameter tanaman $P$. falcataria memiliki grafik pertumbuhan dengan kecenderungan yang sama pada seluruh petak perlakuan dan kontrol, yang berarti bahwa perlakuan tidak memberikan dampak yang signifikan terhadap pertumbuhan tanaman $P$. falcataria, atau dengan kata lain bahwa pemberian perlakukan dengan herbisida tidak menghambat pertumbuhan tanaman $P$. falcataria. Tidak dilakukan uji statistik untuk mengetahui perbedaan diameter antar perlakuan karena dari data dan gambar telah memperlihatkan kecenderungan pertumbuhan yang sama untuk masing-masing perlakuan. 
D ia $m$ e te $r$

( c m )

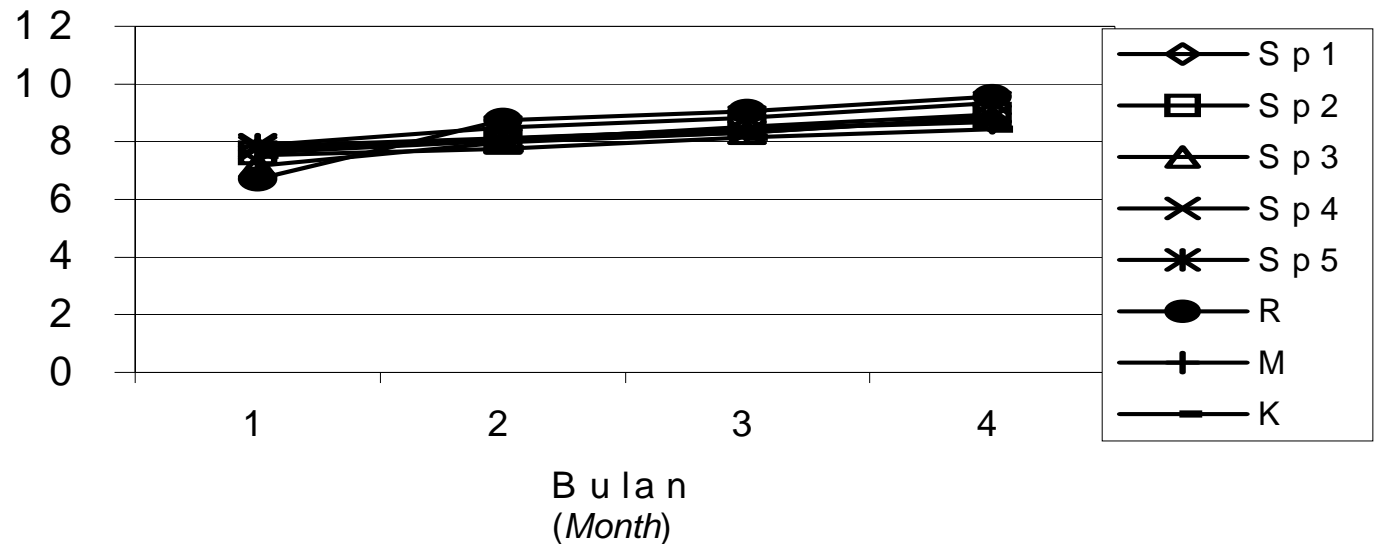

Gambar (Figure) 1. Grafik pertumbuhan diameter rata-rata tanaman Paraserianthes falcataria pada berbagai perlakuan di Parung Panjang, Jawa Barat (Graph of average diameter growth of Paraserianthes falcataria plantation at several treatments in Parung Panjang, West Java).

Efektivitas aplikasi herbisida Monoamomium Glifosat dalam pengendalian gulma di bawah tegakan Paraserianthes falcataria dapat dilihat pada Gambar 2 dan Gambar 3.

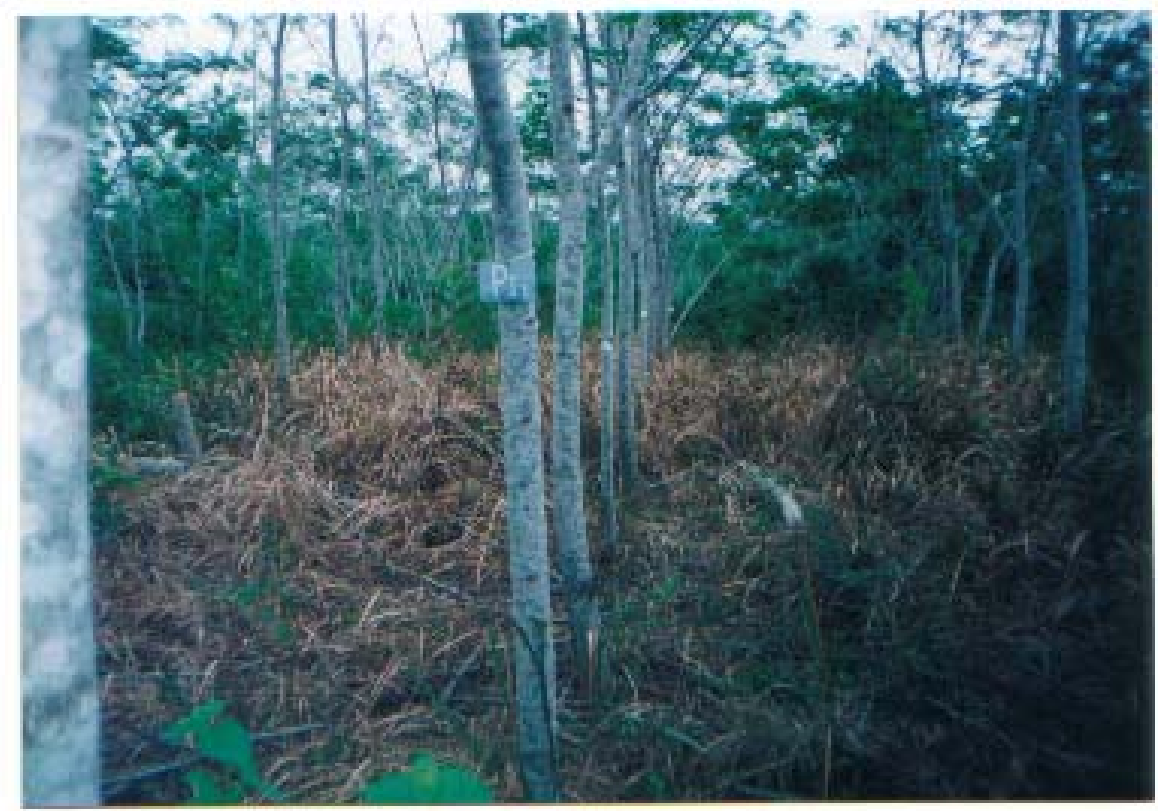

Gambar (Figure) 2. Hasil aplikasi herbisida Monoamomium Glifosat dalam mengendalikan gulma di bawah tegakan Paraserianthes falcataria di Parung Panjang, Jawa Barat (The result of application of monoamomium glyphosate herbicide to control weeds under Paraserianthes falcataria plantation in Parung Panjang, West Java). 


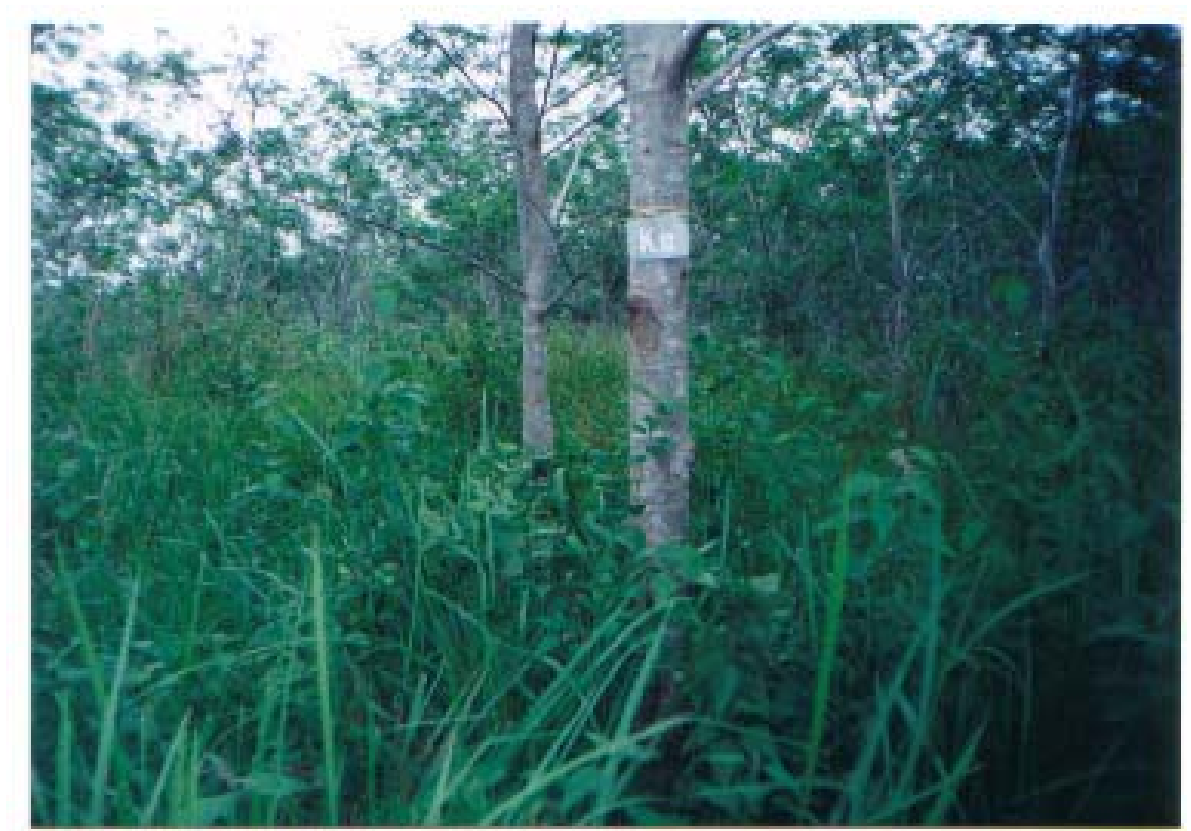

Gambar (Figure) 3. Petak kontrol pada percobaan pengendalian gulma dengan menggunakan Monoamomium Glifosat herbisida di bawah tegakan Paraserianthes falcataria di Parung Panjang, Jawa Barat (Control plots of weed control trial using monoamomium glyphosate herbicide under Paraserianthes falcataria plantation in Parung Panjang, West Java).

\section{Pertimbangan dalam Penggunaan Herbisida}

Penggunaan herbisida dalam pengendalian gulma termasuk juga pengendalian hama, dan penyakit merupakan salah satu alternatif yang aplikasinya memerlukan pertimbangan yang mendalam. Penggunaan herbisida (pestisida) tidak dibenarkan secara luas dan berlebihan karena dapat mengganggu lingkungan dalam bentuk pencemaran lingkungan, mematikan organisme (parasit dan predator) bukan sasaran, menimbulkan kekebalan dari jenis gulma tertentu serta dapat menimbulkan keracunan terhadap manusia atau hewan lain.

Meskipun secara umum memiliki dampak negatif, penggunaan herbisida dapat menjadi alternatif pilihan karena daya basminya yang efektif terhadap berbagai jenis gulma yang tidak dikehendaki dan merugikan tanaman pokok. Berbagai pertimbangan dalam penggunaan herbisida untuk menekan pertumbuhan gulma diantaranya adalah:

a. Herbisida memiliki sifat yang cepat terurai dan tidak meracuni tanaman pokok, lingkungan dan manusia.

b. Diperlukan dosis minimum yang tepat sehingga penggunaannya efektif dan efisien

c. Harga herbisida tersebut cukup ekonomis untuk diaplikasikan dalam skala perusahaan. Dalam skala hutan tanaman industri, biaya aplikasi herbisida termasuk biaya yang harus diperhitungkan dalam biaya produksi, sehingga hasil dari pengusahaan hutan tanaman industri masih memberikan keuntungan secara ekonomi.

d. Merupakan alternatif terakhir apabila tidak tersedia tenaga pemeliharaan secara manual. 


\section{KESIMPULAN}

1. Kondisi kawasan hutan tanaman dengan jenis tanaman pokok Paraserianthes falcataria berumur dua tahun relatif terbuka sehingga jenis gulma paling dominan yang dijumpai adalah jenis yang butuh cahaya (intoleran) yaitu Imperata cylindrica Beauv. dengan Nilai Penting 75,20 \%.

2. Penggunaan herbisida merupakan salah satu alternatif metode yang dapat diterapkan dalam mengendalikan gulma yang mengancam pertumbuhan tanaman kehutanan.

3. Salah satu jenis herbisida yang dapat diaplikasikan adalah herbisida dengan bahan aktif Monoamonium Glifosat yang dapat digunakan sebagai sarana pemeliharaan tanaman kehutanan dari gangguan gulma di bawah tegakan Paraserianthes falcataria (L.) Nielsen.

4. Herbisida Monoamonium Glifosat dengan dosis minimum 4,5 liter/ha cukup efektif untuk mengendalikan gulma Imperata cylindrica Beauv., Borreria latifolia DC. and Mikania micrantha Will. Sedangkan untuk gulma Chromolaena odorata DC. herbisida ini tidak efektif menekan pertumbuhannya.

5. Aplikasi herbisida Monoamonium Glifosat di bawah tegakan Paraserianthes falcataria (L.) Nielsen berumur dua tahun tidak menimbulkan gejala keracunan pada semua tingkat dosis yang dicobakan.

6. Dalam penggunaan herbisida pengendali gulma, hal yang perlu dipertimbangkan adalah harga herbisida (nilai ekonomis), ketersediaan tenaga, efektivitas herbisida dan dampaknya secara keseluruhan terhadap lingkungan.

\section{UCAPAN TERIMA KASIH}

Penulis mengucapkan terimakasih kepada Dr. Drs. H. Bismark, peneliti senior pada Pusat Litbang Hutan dan Konservasi Alam, yang telah memberikan sumbangan saran yang berharga selama proses penulisan naskah ini.

\section{DAFTAR PUSTAKA}

Komisi Pestisida. 1994. Metode Standar Percobaan Efikasi Pestisida. Komisi Pestisida Departemen Pertanian. Jakarta.

Lembaga Penelitian Tanah. 1966. Peta Tanah Tinjau Daerah Jawa Barat. Lembaga Penelitian Tanah. Bogor

National Academy of Sciences. 1978. Tropical Legumes: Resources for the Future. National Academy of Sciences. Washington DC.

Odum, E.P. 1971. Fundamental of Ecology. Third Edition. W.B. Sounders and Co. Philadelphia London Toronto.

Schmidt, F.H. dan J.H.A. Ferguson. 1951. Rainfall types based on wet and dry period ratios for Indonesia with Western New Guinea. Verh. No. 42. Direktorat Meteorologi dan Geofisika. Jakarta. 
Soerianegara, I dan A. Indrawan. 1978. Ekologi Hutan Indonesia. Proyek Peningkatan Pengembangan Perguruan Tinggi. Fakultas Kehutanan. Institut Pertanian Bogor. Bogor

Steel, R.G.D and J. H. Torrie. 1980. Principles and Procedures of Statistics. A Biometrical Approach. International Student Edition. McGraw-Hill International Book Company. Auckland-Tokyo. 633 p 